\title{
DEPOSITION OF GOLD WITHOUT EXTERNAL CURRENT SOURCE
}

\author{
Franz Simon \\ Degussa Electroplating, \\ D-7070 Sibwäbisch Gmünd \\ Germany
}

The relative merits of different plating methods are discussed and a new type of electrolyte for autocatalycic gold plating is described. The chemical system of this bath has an ideal combination of properties such as stability and high deposition speed, combined with long bath life and high meral turnover.

The bath's composition, maintenance and sensitivity to contaminants are discussed, and its operating characterisrics and the properties of the gold coatings formed from ir are presented. Areas suitable for its application are suggested.

\section{INTRODUCTION}

For the deposition of metals from solutions conraining metal salts, negarive electrical charges are required which convert the positively charged metal ion by so-called 'rcduction' into the zero-valent state, i.e. into the merallic form,

In the usual case of clectrolyric metal deposition an external source of current provides the necessary charges for reduccion at the carhode.
In this arricle two deposirion methods are discussed ( $f .[1])$ which do nor depend on such an external source of current. The charges required for the deposition in these processes are supplied either by charge exchange reactions or are derived from chemical reducing agents (Table 1). In charge exchange processcs, a rclatively less noble metal, usually the basis marcrial, dissolves and the more noble meral ion in the solution is reduced and deposited on the substrate. Such processes are referred ro as immersion or displacement plating processes. 
Charge exchange:

$\mathrm{Au}^{+}+\mathrm{Me}^{0} \Rightarrow \mathrm{Au}^{0}+\mathrm{Me}^{+}$

$\mathrm{Me}^{0}$ is less noble than $\mathrm{Au}$, is substrate or auxiliary anode

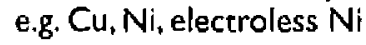

\section{Chemical reduction:}

$\mathrm{Au}^{+}+\mathrm{R} \Rightarrow \mathrm{Au}^{0}+\mathrm{R}^{+}$

$R$ is organic or inorganic non-metallic reducing agent, e.g. $\mathrm{NaBH}_{4}, \mathrm{DMAB}, \mathrm{N}_{2} \mathrm{H}_{4}$, $\mathrm{NH}+2 \mathrm{OH}$ erc.
Table 1

Gold deposition without external current source
In the case of chemical reduction processes on the other hand, a suitable chemical compound-a reducing agenr - supplics the necessary negarive charges. The reducing agent is oxidized at the same time. Such processes are usually referred to as autocatalytic or clectroless plating process. The basic mechanisms of the two types of gold deposition withour the application of excernally generared electric curtent are summarized in (Table 1).

\section{REASONS FOR USING GOLD-PLATING PROCESSES WITHOUT EXTERNAL CURRENT SOURCE AND FIELDS OF APPLICATION}

These processes are used wherever electrically insulated areas on parts or surfaces that cannot be contacted are to be gold-plated. Sometimes the aim is just simply so deposit very thin (e.g. $0.1 \mu \mathrm{m}$ ) layers uniformly on bulk arricles or to reach an oprimally uniform thickness distribution which is independent of the coating thickness. Characteristic of all electroless processes is the possibility of achieving uniform coaring thicknesses all over the articles to be plated if the electrolyte is stirred and/or the articles are moved appropriately. They can be used for the uniform internal and excernal coating of hollow articles into which the electric field in an electrolytic process would not spread so that electrolycic internal deposition on internal surfaces would be difficult or impossible.

As will be descrihed below, gold-plating without an external currene source is used only where electrolytic processes - processes with an external source of current - cannot be used (Table 2). Chemical proc- esses, particularly for thick layers, arc more complicated to operate, considcrably slower and thus also more expensive than elecrrolytic processes. This is mainly caused by their low deposition speeds and also by the costs of the reducing agents. Electrolytic processes work faster and are easier to handle and rhus cheaper.

The meral turnover possible is also very much higher for electrolycic processes than for chemical processes.

Typical fields of application of clectroless reductive gold-placing are in the electronics industry, c.g. on princed circuit boards, and in semiconductor electronics. Such applicacions include contact areas, bonding surfaccs on chip carriers, parricularly ceramics, parts with glass-insulaced bushings, transiscor parts, cascs, and many orhers.

Table 2

Disadvantages of gold deposition without external current source in comparion with electrolytic processes

\section{Immersion gold plating}

- Very slow $(0.1-0.3 \mu \mathrm{m} / \mathrm{h})$

- Decreasing deposition speed

- Limited thickness $(0.1-0.3 \mu \mathrm{m})$

- Pitting corrosion possible

\section{Electroless gold plating}

- Slow $(2.0 \mu \mathrm{m} / \mathrm{h}$ and more; electrolytically: $>60 \mu \mathrm{m} / \mathrm{h}$ rack)

- Very alkaline $(\mathrm{pH} 13-14)$

- Very sensitive to contamination (self-decomposition)

- Limiced life-time 


\section{GOLD PLATING WITHOUT EXTERNAL CURRENT SOURCE BY CHARGE EXCHANGE}

As mentioned above, in gold plating of this type the tclarively less noble basis material dissolves, the corresponding metal ions go inco solurion, the more noble gold, which still is in solution in the form of ions, acquires the electrons and is deposited on the basis material. This process can also be called a form of corrosion.

An important feature of this process is the fact that the charge exchange comes to a standstill as soon as a sufficiently chick and dense gold layer has been deposited (Figure 1, lefr), so that the basis material cannor be dissolved any longer. The coating thickness which can usually be achieved is about 0.1 to $0.3 \mu \mathrm{m}$, depending on the kind of substrate material and its surface quality, and the composition or the kind of gold electrolyte used.

If the suhstrate is very rough, if there are inhomogeneities and defects in the substrate, or if the gold electrolyte contains halogenide ions as accivators and complexing agens, the process may continue with pitring corrosion in the basic matcrial until coating thicknesses of several micrometres of gold are rached (Figure 2, page 19). Necdless to say, howerer, a part can be seriously danaged by pitcing corrosion so that this process must be avoided (loss of matcrial, adhesion problems).

The main characteristics (Table 3 , lcft) of the charge exchange process are the low deposition speed, the decrease of deposition speed with time, the limired coating thickness, and the fundamenal risk of pitring corrosion in the basis naterial.

Advantages are the casy bath maintenance and the good acrivat- cion effect, i.e. good adhesion on nickel and coppet. Fucthernote, overplaring is excluded.

Typical bath compositions and operating parameters for immersion gold plating as reporred in the literature are as follows:

$$
\begin{aligned}
\text { Au: } & 1-5 \mathrm{~g} / 1 \\
\text { NH: } & 1-20 \mathrm{~g} / 1 \\
\text { Cicric acid: } & 10-100 \mathrm{~g} / \mathrm{l} \\
\text { Complexing agent: } & 0.5-20 \mathrm{~g} / 1 \\
\text { pH ranges: } & 3-6,7-8 \\
\text { lemperature: } & 70-95^{\circ} \mathrm{C}
\end{aligned}
$$

Data in respect of two commercially available baths can be found in Table 4 (page 18). There are different batb modifications for different basis materials. They are among other things disringuished by the fact that they do not conrain halogeniele ions.

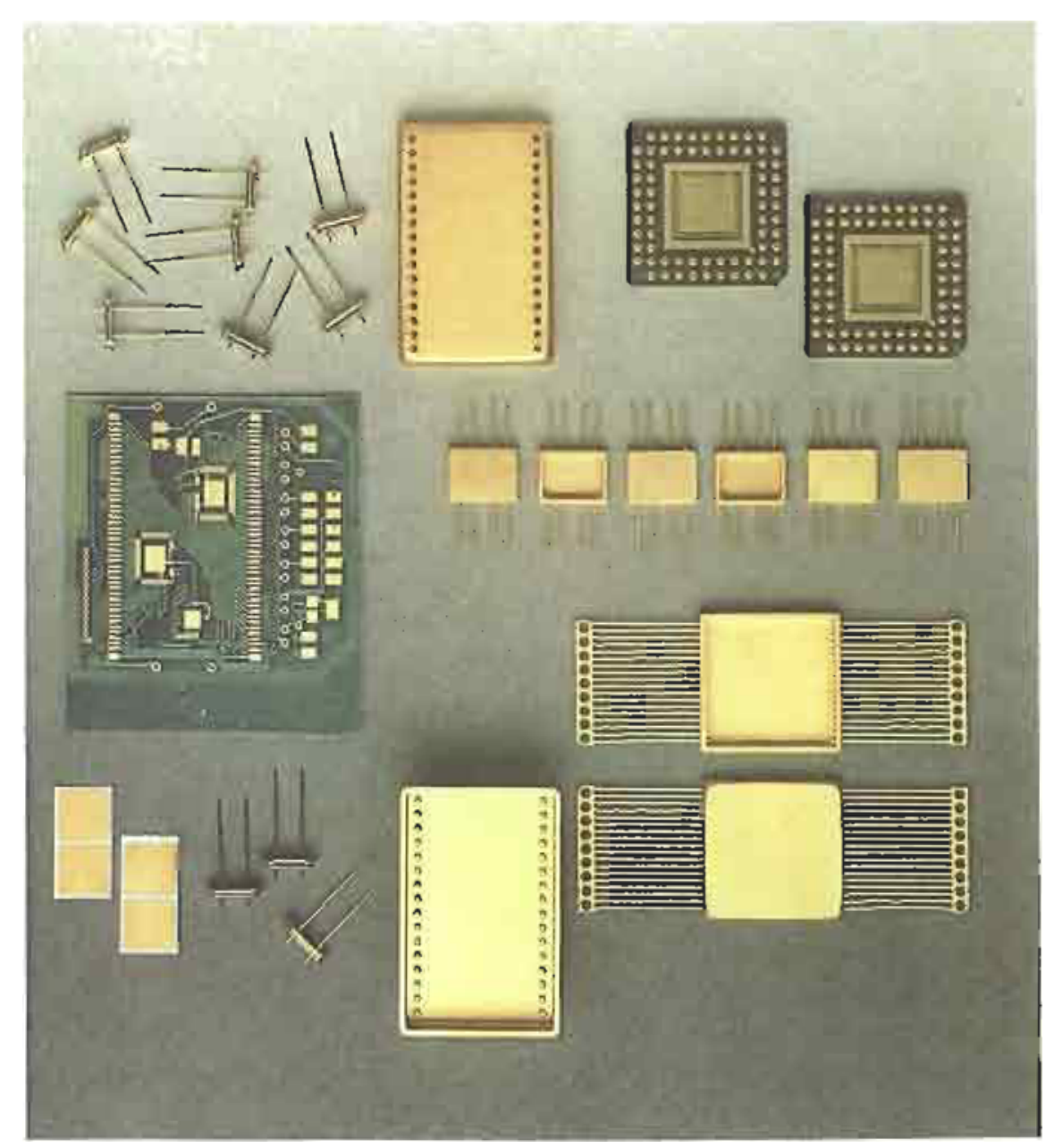

Examples of electronic components plated with electroless processes 


\section{EXTERNAL CURRENT \\ SOURCE \\ BY CHEMICAL \\ REDUCTION}

\section{General Remarks and a Short Survey of the Literature}

The dcposition of gold on a gold substrate is the main distiguishing mark of electroless gold-plating by chemical reducrion in a process working autocatalyrically. The gold substrate or an already present gold layer (electrodeposited or electrolessly deposited) must have an autocatalytic offect on the further deposition. Only if it is guaranteed that this is the case and that the base substrate (basis material of $\mathrm{Cu}, \mathrm{Ni}, \mathrm{etc}$.) does not participate in the deposition process, may the process be called chemical gold-plating.

The difference berween the charge exchange process and chemical gold-plating is impressively shown

Table 3

Gold deposition without external curnen source: topical propertics

\section{Charge exchange (immersion):}

$\mathrm{Au}^{+}+\mathrm{Me}^{0} \Rightarrow \mathrm{Au}^{0}+\mathrm{Me}^{+}$

- very low deposition speed

- decreasing deposition speed

- limited layer thickness

- pitting corrosion on the basis material possible
Chemical reduction (electroless):
$\mathrm{Au}^{+}+\mathrm{R} \Rightarrow \mathrm{Au}^{0}+\mathrm{R}^{+}$
- relatively high deposition speed
- constant deposition speed during bath life
- limized layer thickness
- no pitting corrosion

in Figure 1. The gold is reduced at a constant rate if the orher parameters are kept constant or controlled correctly. Theoretically, unlimited coating rhicknesses are possible.

Sometines substrates, c.g. metallized ceramics, must be previously activated in a suitable way by seeding or they must be intermediately coated. During the chemical gold-plating a short charge exchange reaction always takes place first, until a catalyrically working gold layer has been formed. Thus, ions from the basis matcrial get into the gold electrolyte, and may adversely affect its lifetime.

A variety of bath formulations for chemical gold-plating can be found in the literature (Table 5 , page 18). Not only different gold compounds like $\mathrm{KAu}(\mathrm{CN})_{2}$, $\mathrm{Au}$ $\mathrm{CN}, \mathrm{KAu}(\mathrm{CN})_{4}$ and $\mathrm{HAuCl}_{4}$ are used for this purpose, but also various reducing agents such as sodium hypophosphite, hydrazine, hydroxylamine, N,N-diethylglycine, formaldehyde, thiourea, $\mathrm{Na}$ $\mathrm{BH}_{4}$, and dimethylamine botane (DMAB). The $\mathrm{pH}$ ranges from 


\begin{tabular}{|c|c|c|c|c|}
\hline \multirow{10}{*}{$\begin{array}{r}\text { Table } 4 \\
\text { Comparison of some } \\
\text { parameters of } \\
\text { immersion and } \\
\text { clectroless gold plating } \\
\text { processes }\end{array}$} & & AURUNA 511 & AURUNA $^{(1)} 512$ & AURUNA ${ }^{\circledR} 515$ \\
\hline & Mechanism: & immersion & immersion & $\begin{array}{l}\text { electroless } \\
\text { (reduction) }\end{array}$ \\
\hline & Base material: & $\mathrm{Cu},(\mathrm{Ni})$ & $\mathrm{Ni}, \mathrm{Ni} / \mathrm{Fe}$ & $\mathrm{Au}, \mathrm{Cu}$ \\
\hline & Gold concentration: & $4 \mathrm{~g} / 1$ & $3 \mathrm{~g} / \mathrm{l}$ & $2.5 \mathrm{~g} / \mathrm{l}$ \\
\hline & Temperature: & $90-98^{\circ} \mathrm{C}$ & $90-98^{\circ} \mathrm{C}$ & $75^{\circ} \mathrm{C}$ \\
\hline & $\mathrm{pH}$ value: & Cu: 5.8 (Ni: 5.1$)$ & 4.5 & 13.8 \\
\hline & Agitation: & vigorous & vigorous & moderate \\
\hline & Deposition speed: & $0.1-0.3 \mu \mathrm{m} / \mathrm{h}$ & $0.1-0.3 \mu \mathrm{m} / \mathrm{h}$ & $2 \mu \mathrm{m} / \mathrm{h}$ \\
\hline & $\begin{array}{l}\text { Max. deposit } \\
\text { thickness: }\end{array}$ & $0.2-0.3 \mu \mathrm{m}$ & $0.2-0.3 \mu \mathrm{m}$ & unlimited \\
\hline & Halogen ions: & - & - & - \\
\hline
\end{tabular}

very alkaline ( $\mathrm{pH} 13.7)$ in some baths to very acidic ( $\mathrm{pH}$ less than $\mathrm{l}$ ) in other formulations.

There is some doubr as to whether some of these formulations really are genuine chemical processes.
Indeed, in pracrical trials it can be observed that some processes partly work according to the exchange principle.

\begin{tabular}{|c|c|c|c|c|c|}
\hline & Au components & $\mathrm{pH}$ & $t,{ }^{\circ} \mathrm{C}$ & Reducing agents & Authors \\
\hline & $\mathrm{KAu}(\mathrm{CN})_{2}$ & $7-7.5$ & 93 & Na-hypophosphite & Swan, Gostin \\
\hline & $\mathrm{AuCN}+\mathrm{KCN}$ & $7.5-13.5$ & 96 & Na-hypophosphite & Brookshire \\
\hline & $\mathrm{AuCN}+\mathrm{KCN}$ & $3-4$ & $70-80$ & Na-hypophosphite & Ezawa, Ito \\
\hline & $\mathrm{KAu}(\mathrm{CN})_{2}$ & $7-7.5$ & 95 & hydrazine & Swan, Gostin \\
\hline & $\mathrm{HAuCl}_{4}$ & $>10$ & 85 & $\begin{array}{l}\text { hydrazine + sulfite } \\
\text { + hydroxylamine }\end{array}$ & Luce \\
\hline & $\mathrm{KAu}(\mathrm{CN})_{2}$ & $5-5.5$ & 90 & $\mathrm{~N}, \mathrm{~N}$-diethylglycine & Walton \\
\hline & $\mathrm{KAu}(\mathrm{CN})_{2}$ & alk. & $70-80$ & $\begin{array}{l}\text { hypophosphite } \\
\text { + formaldehyde }\end{array}$ & $\begin{array}{l}\text { McCormach/ } \\
\text { Zeblinski }\end{array}$ \\
\hline & $\mathrm{KAu}(\mathrm{CN})_{2}$ & $6.5-7$ & $83-90$ & thiourea & Oda/Hayashi \\
\hline & $\mathrm{KAu}(\mathrm{CN})_{2}$ & alk. & 75 & $\mathrm{NaBH}_{4}$ & Okinaka \\
\hline & $\mathrm{KAu}(\mathrm{CN})_{2}$ & alk. & 85 & $\begin{array}{l}\text { dimethylaminoborane } \\
\text { (= DMAB) }\end{array}$ & Okinaka \\
\hline & $\mathrm{HAuCl}_{4}$ & 13 & & DMAB & McCormack \\
\hline & $\mathrm{HAuCl}_{4}$ & 10 & & $\begin{array}{l}\text { DMAB } \\
\text { + formaldehyde }\end{array}$ & Rick \\
\hline & $\mathrm{KAu}(\mathrm{CN})_{4}$ & $>1$ & & $?$ & Heraeus \\
\hline & $\mathrm{KAu}(\mathrm{CN})_{2}$ & alk. & 90 & DMAB & $A C R$ \\
\hline & $\mathrm{KAu}(\mathrm{CN})_{2}$ & alks. & 75 & DMAB & Uyemura \\
\hline $\begin{array}{l}\text { Table } 5 \\
\text { 7ypes of clectroless gold } \\
\text { baths (after [3]) }\end{array}$ & $\mathrm{KAu}(\mathrm{CN})_{2}$ & 13.7 & 75 & DMB & Degussa \\
\hline
\end{tabular}




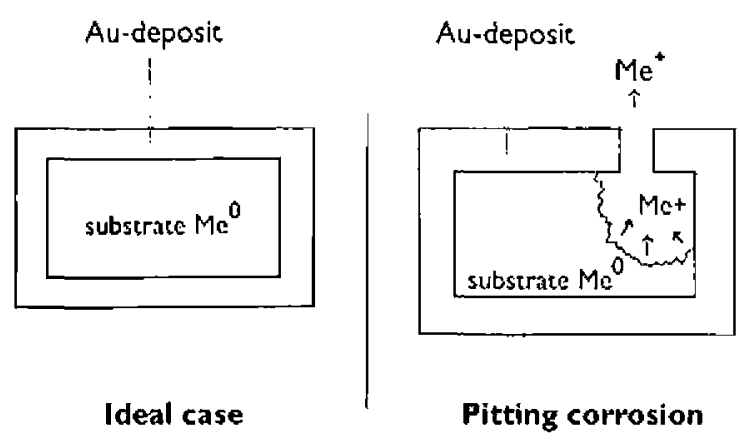

Figure 2

Pitting corrosion when gold plating with an immersion process (charge exchange)

Systems based on the usc of $\mathrm{KAu}(\mathrm{CN})_{2}$ and the reducing agents $\mathrm{NaBH}_{4}$ or DMAB (dimethylaminoborane) have been examined most extensively and probably have been the most successful in practice. Our knowledge of these rypes of bath is cssentially based on the work of Okinaka [2] and his collcagues. Okinaka showed in his work that the reducing agents $\mathrm{NaBH}_{4}$ and DMAB react according to different mech- anisms and that baths and their behaviour therefore depend among orher things on the hydroxide concentracion.

He showed that in both cases the $\mathrm{BH}_{3} \mathrm{OH}^{-}$ion is the actual reducing agent which itself is formed in a preliminary reaction appropriate ro the reducing agent involved (Figure 3).

Thus, $\mathrm{NaBH}_{4}$ first must partially hydrolyze and this is favoured in the acidic or less alkaline $\mathrm{pH}$ range (Figure 3 a).

In the case of $D M A B$, the amine (dimethylamine) artached to the $\mathrm{BH}_{3}$ molecule inust be displaced by an $\mathrm{OH}^{-}$ion in order to generate $\mathrm{BH}_{3} \mathrm{H}^{-}$ions (Figure $3 \mathrm{~b}$ ). It is clear that this displacement reacrion is favoured in the very alkaline $\mathrm{pH}$ range, where many $\mathrm{OH} \cdot$ ions are present.

In addirion, Okinaka confirmed that $\mathrm{NaBH}_{4}$, even during rest periods at room temperature, decomposes more easily by hydrolysis than $\mathrm{DMAB}$, which is more stable. Okinaka prefered $\mathrm{NaBH}_{1}$ because, according ro his findings, higher deposition speeds could be reached with it than witl DMAB. Okina-ka has also identified fundamental problems with regard to the liferimes of such barhs, namely their sensitivity to metallic contaminants, the need to regencratc and replenish them and the maintaining of a constant deposicion speed during the lifetime of a bath.

The fundamental weakness of a chenical gold bath is inherent in the system itself: it is a thermodynamically unstable system, a redox system, which would like to react only in one direction, namcly in the direction of gold deposition. The main task now is to kecp the system sufficiently stable on the one hand and, on the orher hand, to destabilize in sufficienrly in order to reach acceprable deposition speeds. This is a difficult compromise which in the end leads ro an optimization of the system.

Figure 3

Electroless gold deposition wing borobydrides 
Table 6

AURUNA 515 - Bath chamateristics

Type:

$\mathrm{pH}$ value:

electroless (reductive)

alkaline, cyanidic

Au content:

Temperature:

Density:

Deposition speed:

Loading:

Bath agitation:

Rack movement:

Barrel movement:

Filtration:

Exhaust:

Max. thickness:

MTO:
$13.7-14 \quad\left(20^{\circ} \mathrm{C}\right)$

$2.5 \mathrm{~g} / 1 \quad(2.0-2.5)$

$75^{\circ} \mathrm{C} \quad(73-77)$

$1.030 \quad\left(20^{\circ} \mathrm{C}\right)$

$2 \mu \mathrm{m} / \mathrm{h} \quad$ (up to $6 \mu \mathrm{m} / \mathrm{h}$ )

$1-1.5 \mathrm{dm}^{2} / 1$

low

none

slow

not required

required

unlimited $\quad(50-100 \mu \mathrm{m})$

$14 \times$ (rack)

$7 \times$ (barrel)
Table 7

AURUNA 515 - Deposit chamateristics

\begin{tabular}{ll|}
\hline & \\
Au content: & $99.9 \%$ \\
Hardness: & $60-70 \mathrm{HV} 0.015$ \\
Classification: & III A, acc. to MIL-G-45204 B \\
Density: & appr. $19 \mathrm{~g} / \mathrm{cm}^{3}$ \\
Appearance: & fine-grained smooth, matte \\
Bondability: & excellent \\
Solderability: & excellent \\
\hline
\end{tabular}

\section{Bath Composition}

The basic components of the new AURUNA 515 bath are $\mathrm{KAu}(\mathrm{CN})_{2}, \mathrm{KCN}$, alkali hydroxidc, accclerator, depolarizer, and DMAB or dimethylaminoborane as reducing agent. The bath characteristics are presented in Table 6. The low gold content of $2.5 \mathrm{~g} / 1$ has to be emphasized as well as the relatively low bath temperaturc of $75^{\circ} \mathrm{C}$ and the maximum possible metal turnover, which is considerably better than for comparable state-of-the-art processes.

The deposition speed was purposely limited to $2 \mu \mathrm{m} / \mathrm{h}$, because the development was aiming at an optimal compromisc. A higher deposition speed would have increased the risk of random deposition of gold and could have limited the life of the bath.

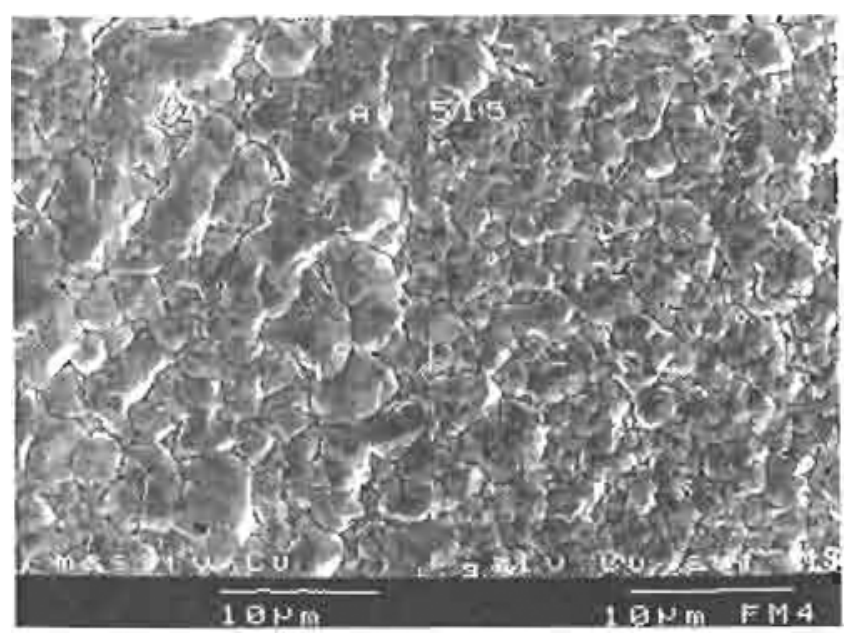

Figure 4

Surface simcmire of clectroless gold (AURUNA 515) SEM-photo, $\times 3000$ 


\section{Coating Properties}

The properties of the gold deposits from AURUNA 515 baths are summarized in Table 7. These gold layers are soft fine gold contings of high purity, suitable for bonding and soldering purposes. The surface structures of rwo coatings are shown in a micrograph obtained by scanning electron microscopy (Figure 4).

\section{Bath Maintenance}

In general, the bath maintenance is influenced by the following factors during the opcration of the bath: replenished in two steps - gold-dependent and timcdependent. The decisive time is the rime during which the bath is at operating temperature.

Cyanide has a stabilizing effect in chemical gold baths which leads to a decrease in the deposition speed. On the one hand a minimum content of cyanide of several $\mathrm{g} / \mathrm{l}$ is necessary because otherwise the bath would decompose spontaneously. On the other hand, a rising cyanide conrent during the lifetime of the bath may bring the deposition to a standstill.

By adding an acceletator, this problen can be elegantly solved without having to remove the cyanide from the system or having to bind it (Figure 6). Binding the cyanide wirh the aid of AuCN (simultane-
- decreasing gold content (caused by deposition)

- decreasing content of reducing agent (caused by Au deposition and by self-decomposition)

- rising $\mathrm{CN}^{-}$concentration (resulting from decomposing $\mathrm{K}$ $\left.\operatorname{Au}(\mathrm{CN})_{2}\right)$

- decreasing $\mathrm{OH}^{-}$content (caulsed by attachment of $\mathrm{OH}^{-}$ions ro $\mathrm{BH}_{3}$ )

Other factors, like remperarure and srirring speed, can be easily kept constant.

The effect of changing bath and operating characteristics on the deposition speed can be secn in Table 8 (page 22).

Gold content, content of the reducing agenr, and $\mathrm{OH}^{-}$content can be corrected by replenishing the corresponding components. With regard to the consumprion of the reducing agent, rwo causes should be distinguished: the consumption which is caused by the reduction reaction and that caused by spontancous decomposition.

An example of an cmpirically found replenishment schedule to be used in actual practice is shown in Figure 5. The reducing agent is
Example: $\quad$ I l bath, $1 \mathrm{dm}^{2} /: 2.5 \mu \mathrm{m} / \mathrm{h} ; 2.6 \mu \mathrm{m}$, continuous rack plating

replenishmens: $x$ ) rclated co Au

$x x)$ related to time

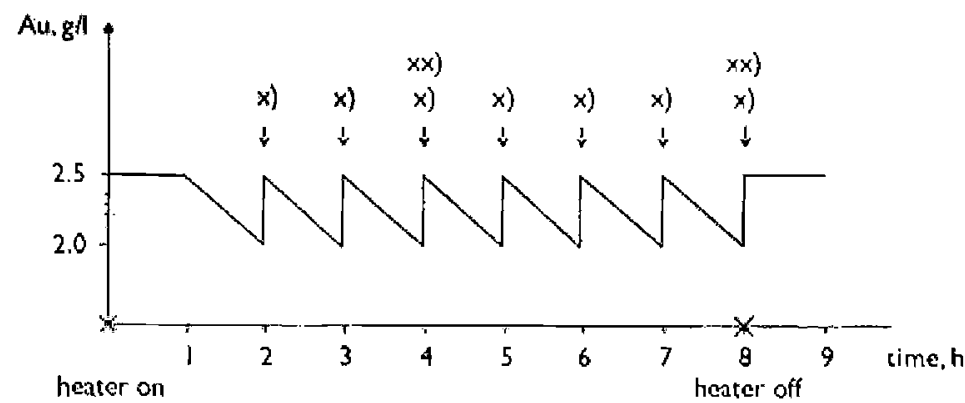

Example: $\quad$ I $\quad$ bath, $1 \mathrm{dm}^{2} / 1$, continuous rack plating

Au concentration: $2.5-2.0 \mathrm{~g} /$, permitted range

Deposition speed: $2.5 \mu \mathrm{m} / \mathrm{h}$, constantly

$0.5 \mathrm{~g}$ Au plated out

$2.6 \mu \mathrm{m} \mathrm{Au}$ deposit thickness is achieved for each sample

about $! \mathrm{h}$ exposure time in bath per sample to achieve $2.6 \mu \mathrm{m}$

$$
\begin{array}{ll}
\text { x) replenishrment (Au-related) } & \text { xx) replenishment (timc-related) every } 4 \mathrm{~h} \\
0.5 \mathrm{~g} \mathrm{Au} & \left(2 \mathrm{ml} /\left(\mathrm{ll}_{1}, 1\right)\right. \\
5.0 \mathrm{mi} \text { replenisher solution } & 2 \mathrm{~m} /\left(\mathrm{h}_{1}, \mid\right) \times 4 \mathrm{~h} \times 1 \mathrm{I}= \\
3.75 \mathrm{ml} \text { arcelerator } & 8 \mathrm{ml} \text { replonisher solution }
\end{array}
$$

Figure 5

AURUNA 515 - Replenishment 


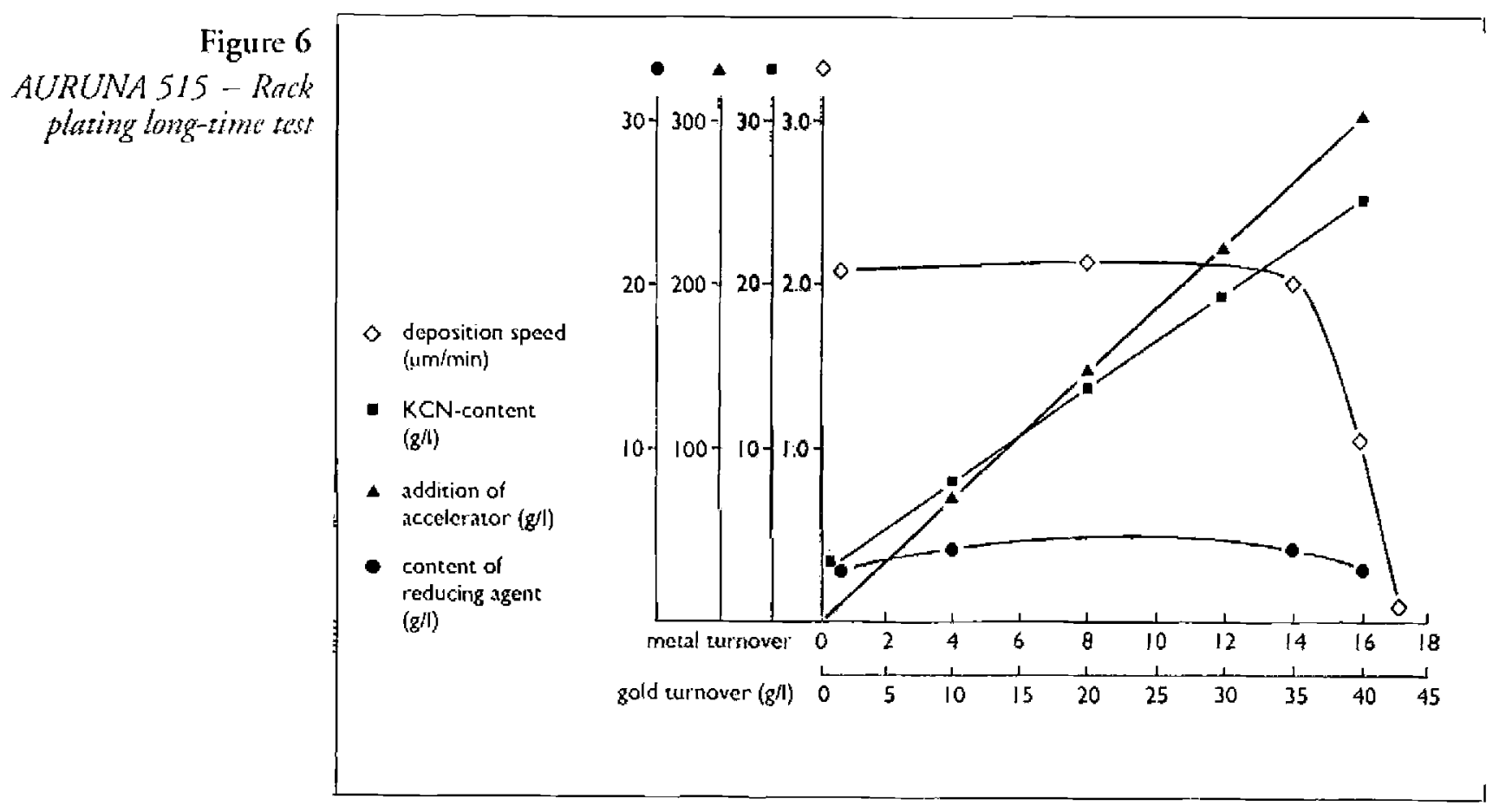

ously with gold replenishmene) was given up because such a scep would require a grear deal of equipment to guarantec that on the one hand AuCN is dissolved fast cnough as cyanide is consumed and, on the other hand, not roo much cyanide is captured and the gold content does nor rise inadmissibly. Furrhermore, no solid particles of AuCN must ger into the bath because these would act as nuclei for random deposirion.

Table 8

AURUNA 515 - Effects of componentiparamoters on plating speed ( $V$ )

\begin{tabular}{lllll|}
\hline Gold & $\downarrow$ & $\Rightarrow$ & $V \downarrow$ \\
Reducing agent & $\downarrow$ & $\Rightarrow$ & $\vee \downarrow$ \\
Temperature & $\downarrow$ & $\Rightarrow$ & $V \downarrow$ \\
\hline $\mathrm{pH}$ value & $\downarrow$ & $\Rightarrow$ & $V \downarrow$ \\
$\mathrm{KCN}$ & $\uparrow$ & $\Rightarrow$ & $V \downarrow$ \\
Accelerator & $\uparrow$ & $\Rightarrow$ & $V \uparrow$ \\
\hline Accelerator empirically compensates the \\
inevitable increase of KCN associated \\
with metal turnover
\end{tabular}

Wich regard to the deposition speed, the accelcraror neutralizes, so to speak, the effect of surplus cyanide or cyanide formed during the reduction in the barh (Figure 6).

\section{Coating Sequences of Different Substrate Materials}

Copper basis materials (and of course gold coatings chemselves) can be directly chenically gold-plated withour an intermediate liyer, after the obligatory cleaning of the parts by soak cleaning or acidic cleaners.

Nickel coarings should be pre-gilded in an immersion plating bath. AURUNA 512 is suggested for the purpose. Zinc and iron alloys musr also be pre-gilded and the use of the immersion plating bath AURUNA 511 is recommended in order to avoid contamination of the chemically acrive electrolyte.

Barrel-ware of copper or relatively thickly pregilded articles can also be chemically gold-plated withour an intermediate layer. Copper ions in the bath do not affect the plating operation.

Barrel-ware (bulk articles) made of orher basis materials must first be chemically nickel-plared and then pre-gilded in a charge exchange process before 
Table 9

AURUNA 515 - Limits for metallic contaminants

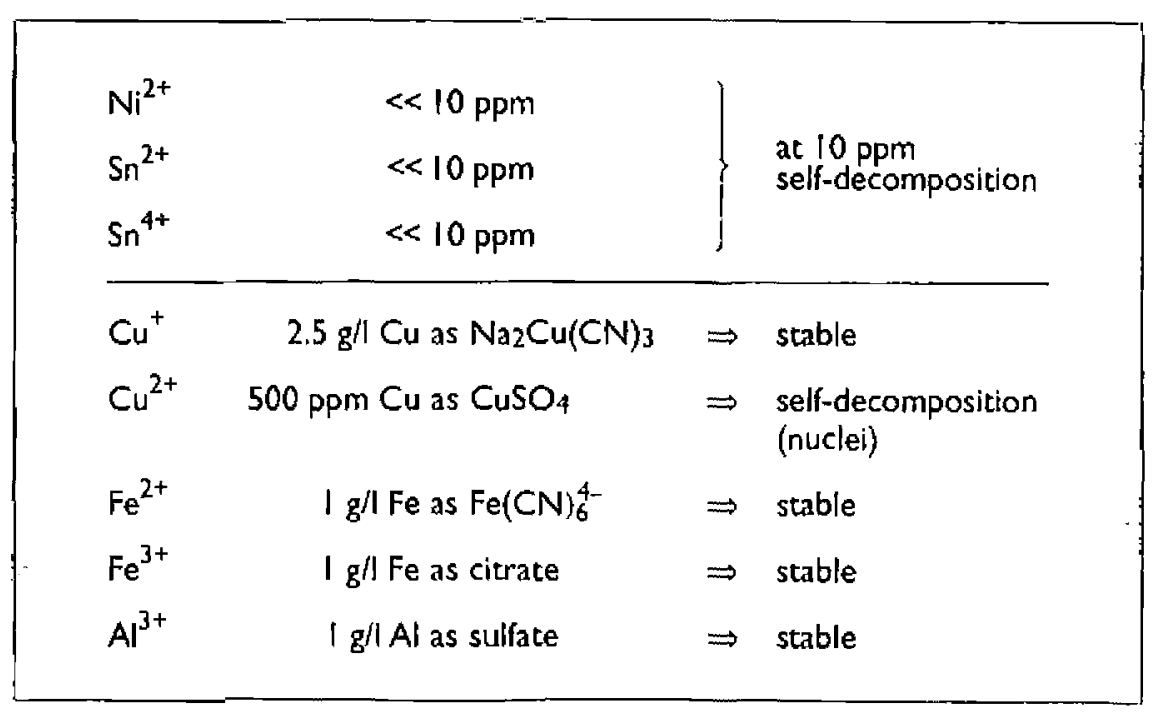

\section{Summary and}

Advantages of the Newly Developed Process

With the now gold electrolyte a system has been created which is an ideal combination of opposite properties such as stability on the onc hand and relatively high deposition speed on the other, combined with a long barh life (Table 10). Per litre of bath, in rack operation metal turnover of up to 14 tines is possible if the bath is suitably maintained, i.c. $14 \times 2.5 \mathrm{~g} / \mathrm{l}=$ $35 \mathrm{~g}$ of Au per litre of bath can be deposited. The specd of gold deposition can be kept constant durthey can subsequently be chemically gold-plated. The use of the AURUNA 512 bath is suggested.

The sensitivity of the chemical gold electrolyte to some metallic contaminants is shown in Table 9.

Table 10

AURUNA 515 - Aduantages and positive properties in comparison with the sate of the art

- Good combinarion of high stability and relarively high deposition speed

- Long life,

i.e, high metal turnover (MTO) possible

Barrel: 7 MTO

Rack: 14 MTO

- Easy maintenance

- Reproducibility of results (bach and deposit properties)

- During bath lifetime no significant changes of bath deposition properties ing the liferime of the bath by adding an accelerator.

Random deposition and bath decomposition do not occur during the whole lifetime of the bath if the drag-in of nickel and tin ions is avoided. This is possible by simply inserting a preliminary charge exchange (immersion) bath. A clean way of working must be observed.

Bath maintenance may be qualified as easy. During the lifetime of the electrolyte no significant changes occur with regard ro the deposition characreristics of the bath and the coaring properries.

\section{References}

1. H.O. Ali and I.R.A. Chrissic, Gold Bulh, 1984, 17(4), $118-27$

2. Y. Okinaka, 'Elcetroluss Gold Deposition using Borobydride or Dimerhylamine Boranc as Reducing Agene', Pha Suff. Finish., 1970, 57, 914-920

3. Y. Okinaka, in 'Gold Plating Technology', edited by F.H. Reid and W. Goldie, Electrochemical Prblications, Ayr, Scotland, 1974 